INFORMATION SOURCES

IN LEGISLATIVE MEDIA:

pro-government bias and diversity

in news making regarding

Brazilian Chamber of Deputies

Copyright (c) 2011 SBPJor / Sociedade Brasileira de Pesquisa em Jornalismo
CRISTIANE BRUM BERNARDES

Postgraduate Program of Center for Training and Improvement

(CEFOR) of the Brazilian Chamber of Deputies

\begin{abstract}
The article analyzes the relationships between the journalists and the sources of legislative media maintained by the Brazilian Chamber of Deputies - TV Câmara, Rádio Câmara, Agência Câmara and Jornal da Câmara. From interviews and participant-observation of the production routines in all four media, one can notice the advantage given to official sources, especially to the congressmen themselves. The dual role of the deputies - sources and publishers of these media - is a complicating factor for the journalist's autonomy. The arguments between the two instances of news making point to the diversity of sources and scopes necessary for media that covet the "public" title.
\end{abstract}

Key words: Brazil. Chamber of Deputies. Legislative media. Journalistic sources. Source diversity.

\title{
INTRODUCTION
}

One of the main facets of news making, the relationship between journalists and sources, has been exhaustively analyzed by several Journalism Theory authors. Our focus is, however, on the relationship between legislative media professionals and their sources. Our concern is the paradox in the relationship established by journalists of the so-called source media (SANT'ANNA, 2008) with the social actors that provide them with information. According to Francisco Sant'Anna, source media are "new media that are offered to the public by professional and social organizations, including segments of the government itself" (2008, p. 9). As stated by Sant'Anna, these media are maintained and managed by social actors who have previously been exclusively information sources.

Other authors also agree (QUEIROZ, 2007; SANT'ANNA, 2008; GONÇALVEZ, 2010) that it is impossible to deny the fact that these source media are organized in a journalistic manner by civilian entities 
and public administration bodies in Brazil. Despite their hybrid character, combining journalistic genders and institutional information - something akin to institutional journalism - the news making of these media shows a clear journalistic organization, even with several critics pointing to an exclusive institutional bias in their products.

These media are maintained and financed by social actors who were previously only sources for conventional media and are now solid news making structures. Besides their obvious role of providing firsthand information for conventional media, a function similar to that of a press agency, these news making structures provide several forms of direct communication with the people, apart from the communication mediated by the mainstream press. In that sense, these media report the most relevant information about the institution to the average audience, promote the visibility of issues and actors relegated to the background by the mainstream media and contribute to the plurality of views and voices in the national news, especially in the political field.

In order to conduct the study, we utilized several complementary research techniques: bibliographical research of the relationship between journalists and sources; participant-observation of the news making routines in the four legislative media; and in-depth interviews with professionals working within these media'. Before analyzing our primary issues, let us consider some data on the current organization of the Communication Secretariat (Secom) $)^{2}$, the agency responsible for managing the four media.

The Chamber's communication facilities are managed by Secom, reporting directly to the Presidency of the Chamber. This system started in 1961, even before the military dictatorship in Brazil. In that year the Broadcasting Service of the Chamber of Deputies was created and the first product was a 20 minute newscast in the government program The Voice of Brazil, in 1963. Until the 1990's, an entity created by Resolution \#20 of 1971, Adirp (Public Relations and Institutional Publicity Bureau), coordinated the work of the four media.

After a series of adaptations occurred during the reestablishment of democracy, the entity was structured in a manner similar to the way it is today and Adirp became the Communication Secretariat (Secom) in 1998. The text justifying the aforementioned changes, signed by the then President of the Chamber, explained that the prior name dated from the 1970's and that it was "completely outdated". According to the document, "the new title includes the area of the Chamber in the generality of its functions", especially at a time in which its tasks were 
extended with the creation of the Chamber's radio and television channels, besides other enterprises.

In 1998, TV Câmara was created and in the following year the news report was fashioned into a daily paper, Jornal da Câmara, in a small format comprising eight pages. During the year of 1999, Rádio Câmara was created, a radio station which broadcasts throughout the Federal District (capital of Brazil) and makes its information available online. In 2000, the process was completed with the formation of Agência Câmara, an online agency responsible for legislative information and the newscasting of parliamentary activities via the Internet.

Apart from these four communication structures, Secom maintains several communication tools intended to divulge information about the institution such as informative Internet pages at Portal da Câmara, guided tours or public relations activities and those involving publishing of the Chamber's image. We focus in this paper, however, on the legislative news making media and not on the institutional communication activities performed by the Communication Secretariat (Secom).

All of the Chamber's media are supervised by the Journalism Coordination, which is responsible for linking the coverage efforts of those media. The Journalism Coordination is also responsible for providing the vehicles with guidance regarding assignments and coverage. Besides these functions, this entity assists the deputies and their assistants in matters of the Chamber and with regard to other communication vehicles. It follows news publishing on TV and websites, fact-checks information on meetings and the presidential schedule and it also establishes contacts with the Presidency for the Chamber's public relations personnel.

All these bodies and subdivisions of Secom have as their primary function managing all the communication which the Chamber of Deputies performs with Brazilian society 4 . In addition to communicating institutionally with its organization's target audience, the entity also performs public information services and journalism through the legislative media. In this sense, in addition to managing of the institution's public image and the visibility of the deputies, the Chamber's communication branches have the responsibility for providing information services for the benefit of the Brazilian population.

\section{Preferred sources}

An important focus of our inquiry that is emphasized by several studies on the news making routines is the relationship between 
journalists and their sources (ALSINA, 1989; FONTCUBERTA, 1993; SOUSA, 2000), especially for their complexity and the amount of factors involved in their objective description. Apart from availability, i. e., being willing to speak when the journalist needs a statement, the source needs to be knowledgeable on the subject and locatable. That means the journalist has to know about the source's knowledge of the subject and also have access to the source. Personal issues such as geniality, friendliness, oral expression and conciseness are also considered by the journalist, in addition to the simple knowledge of the issue. Thus, the journalists covering the Chamber usually describe the deputies as "good" or "bad" sources. It is obviously interesting for many of the deputies to become good sources, despite their ignorance of how to accomplish this.

According to Fontcuberta (1993, p. 57), source selection is one of the differentiating elements between information vehicles, since the journalistic code is shared by every journalist, and thus the production routines of various news vehicles are similar. In this case, we believe the choice of dissimilar sources helps determine differences in the news making practices. Any reporter obviously has to gather data and interview subjects; the manner in which these tasks are performed, however, are not dependent only on the kind of media (radio, TV, paper, Internet) but also on the type of source chosen.

Another important issue, as stated by Alsina (1989, p. 113), is that sources also obey a hierarchical organization depending on their credibility and the sort of information they are able to provide. Thus, a Chief of Police is more valuable as a source than a simple detective if the report calls for the official police version. In some cases, however, the detective may be of more value by being informed of details not personally followed by the Chief. According to the situation and the source type, three types of relationship with the journalist may arise: total independence, cooperation or news making by the source (ALSINA, 1989, p. 117). The latter is especially common when reporting politics, since the government is capable of influencing information by the fabrication of artificial situations that represent and interfere with reality (ALSINA, 1989, p. 115).

Likewise, sources lend some of their credibility and authority to the vehicle (FONTCUBERTA, 1993, p. 58) and assist the journalist in gaining respect by obtaining exclusive information not gathered by other reporters. In this manner, according to the author, the vehicle's informative power reveals itself in relation to the number, quality and pluralism of its sources. The most sought-after sources are those who are prominent and 
esteemed, apart from other features such as productivity, accessibility, trustworthiness, authority and ability to express themselves coherently (GANS, 2004, p. 129-131). Positional power and authority is one of the criteria most used by the media in their quest for sources. Even among actors on the same authority level - deputies, for instance - there is a formal and also an informal hierarchy that is established by the elements highlighted by Gans and others, such as experience, communicational ability, reputation or formal role performed by the source (TRESCH, 2009, p. 71). Charaudeau adds to that list the quality of generating controversy as one of the characteristics sought after by journalists in their sources (CHARAUDEAU, 2007, p. 145).

The journalist's relationship with sources is, nonetheless, capable of creating oppositions, ethical embarrassments and professional issues for both the source and the reporter. These issues come about because it is not uncommon for sources to attempt to use the publication of facts in the press for self-interest, despite the journalist's intention to publish facts which are truthful and important for the society. The journalist may have to face, then, a conflict between professional loyalty and the need for nourishing relationships with their sources (BLUMLER; GUREVITCH, 1986 , p. 90). This relationship is ruled by secrets, or the right to "off the record", that is, the duty the journalist has to keep his sources secret, especially when they provide the journalist with information that may put them at personal or professional risk, which is very common when dealing with politics. Eliane Cantanhêde synthesizes professional common sense about the relationship between journalists and political sources in the following terms:

\footnotetext{
[...] journalists should be close enough to obtain information and far enough so as not to be promiscuous. [...] For the simple reason that their interests are very unlike and generally conflict with each other. Government, parliamentary, courtroom sources - i.e., power sources - only aim to divulge what is in their best interest, and hide what does not favor them. It is usually quite the opposite case with journalists (CANTANHÊDE, 2006, p. 185).
}

In the Chamber, the journalist's main sources of information are the deputies themselves. Apart from them, members of the organized society, specialists, Executive and Judiciary Branch technicians, authorities from the different levels of government and ordinary citizens are also less frequently featured. In the specific case of the deputies, the problem becomes clear because, despite being sources, they exert great power over the vehicles, for they are subject to the Presidency of the Chamber. Thus their dual role as sources and 
"supervisors" or publishers of legislative media is a further complicating element of their relationship with journalists.

An e-mail sent by a manager to TV Câmara's team in November 2009 reveals the added difficulties of this ambiguous relationship. She expressed concern over the lack of a warning to a deputy regarding the fact that an interview was canceled, and notified the other professionals in order to avoid that kind of situation. A few excerpts from it are reproduced below:

1) We had scheduled a meeting with the deputy; the meeting did not go through, everybody knew, except for the deputy who was not warned by us.

2) The interview show is scheduled, the deputy cancels it, and the information does not pass through. The host and the technical team wait for him, needlessly. A phone call is made in order to ask for the deputy's presence and it turns out that he had already notified us that he was not coming to the show.

The issue in both cases is one of bad internal communication and also bad communication with the deputies, a highly flammable mixture. We had our competence, professionalism and accountability recently questioned regarding our conduct with the deputies exactly due to this kind of situation. And it was not pleasant at all.

Besides the basic issue that any source deserves respect and deserves to be warned when an interview is canceled, the memo translates a public fear of conflicts with the deputies. That is, besides deserving respect for being sources, they are in a position of prejudicing the professionals' situation in the vehicles and "nobody wants to pick a fight with them". The warning reveals thoroughly the hierarchy present in the Chamber: the deputies rule, we obey them. It is considered much worse to mistreat one of them than to do the same with a different source.

The Chamber's media professionals nonetheless affirm that their relationship is not as subordinate as an external observer might imagine. One of the interviewed managers, for example, emphasizes the search for a "safe distance" from the parliamentarians.

Isolating oneself from politics in terms of isolating oneself from partisan politics, apart from the issue of who is the (Chamber) President, what he orders. We even try; I believe this is more of a personal characteristic, for I do not know how it would be with the other Director, but I believe that what happened was a policy designed since our beginning, not to be too close to the Presidency, to keep our independence, you know? I have no relationship with the Presidency, with the President. I never ask for anything; if I have to argue about something I take it to my immediate superior, to the Secretary, you know what I mean? I do not like to cross that boundary. I believe it leads to some preferential treatment, some sort of interest game, some request to publish or to not publish something. I find it bad (interview given to the researcher). 


\section{Other non-managerial professionals confirm that the journalists} relationship with the deputies generally is far more distant than the usual link reporters establish with their other sources.

I thought we were going to work here and we would have many sources. It is strange; we do not establish many sources. I do not know if this happens because we seldom cover the same thing or if it is a particular experience of mine. But it is the quality of our coverage that does not allow that.

[...] the mainstream press needs to attract sources much more than we do, for their job is always in question - job security, status, power. For them, status is a much more important issue. In that sense, we have ways of protecting ourselves from that. We do not have to attract and hold the source so it provides us with scoops, we cannot report backstage novelty, gossip, and the mainstream press needs that, because their professionals are their capital. The professional has to be knowledgeable for what reason? If he loses his job, he will be coveted by other vehicles because of his contacts, because he is capable of networking. And we are not (interview given to the researcher).

For some of the professionals, by the way, being distant from usual sources contradicts journalistic rules and makes the work more difficult.

I also am uncertain about the quality of the verifying processes. I believe it is badly done. There is not, I do not see any attempt by reporters and editors to consolidate sources. That is, a real reporter, in a non-institutional press context, feeds from his sources; he has to talk to people. Not a source to give him a scoop, not that, but the people he takes care of, the ones he talks to, he goes back to that guy, he calls that guy. I do not see our reporters behaving like that, that does not concern them. One or two of them might call directly someone. They are too dependent on the production team. They trust the production team too much (interview given to the researcher).

Now it has been decided that a journalist cannot be friends with a source. In fact, there is nowadays a distrustful relationship between the deputies and us journalists. Something I find extremely harmful to our cohabitation and to the accomplishment of work goals. For it is assumed that every deputy is a criminal. This is a very shallow vision of the situation. [...] And this animosity has been created, the deputies are distrustful of us, they do not want to tell us about things. Sometimes I even tell them: "Look, my TV does not accuse anyone". And yet they do not believe me. [...] I do not know if that happens around here with everyone else. I am under the impression that it is very difficult to work here because the level of distrust has gotten too high. It is very difficult to obtain a source here. Most of the sources are among the employees, not the deputies. This is crazy! (interview given to the researcher).

These declarations reveal that the relationship between Chamber reporters and the deputies is very dissimilar from that of the mainstream media reporters with the deputies. There is no personal exchange, a certain mutual group of interests, the personal pressure present when the sources need to show up in a mainstream paper. Probably because 
the deputies know that they are going to be featured in the Chamber's vehicles anyway, even if they do not pressure the reporters and editors personally. When this pressure occurs, it is much more general; it takes place with the President of the Chamber, the Secretariat (Secom) director, not directly with the reporter. In a certain way, the Chamber journalists are freed from the need to contact sources personally, for their relationship with them is much more institutional. Paradoxically, their relationship with the sources therefore exempts the legislative media professionals from more punctual kinds of pressure, as they themselves affirm.

As Cook (2005) emphasizes, journalists rely on sources, but they are not the ones selecting the criteria for evaluating them and including them in their reports. The author reminds us that journalists determine what are the interesting facts, while political actors determine what is important and newsworthy, resulting in a complex process of "newsworthiness negotiation" in order to define "who manages the schedule, what can be asked, where and how it can be asked, and what will be the proper answer" (COOK, 2005, p. 12).

In an environment such as the Chamber of Deputies, however, the journalist does not often have the option to choose which one of the deputies will be his source on a specific subject, since many of the assignments have to do with the newsworthiness of some of the phases of the legislative process. Examples of mandatory sources, due to their direct participation in the activity published, are: an author of a bill, the deputy reporting on the bill in a committee, a deputy requiring a public hearing. These are, so to speak, obvious sources. There is no strategic effort by the deputy to obtain attention or by the journalist to choose the source best able to inform. Thus the source is chosen according to legislative criteria, not journalistic ones, or by means of an undisclosed agenda of the deputy.

In some other cases, although the deputy is not directly involved in the specific legislative process taking place, he is chosen because of his political relevance in the Chamber. Besides the President of the Chamber, there are also party leaders, members of the Chamber's governing body and committee chairmen, both permanent and temporary ones. In these cases, institutional criteria once more dominate news making in this environment.

\section{Pro-government bias of sources}

With respect to the dominance of institutional criteria in the choice of sources, it is necessary to recall that many studies highlight 
the "pro-government bias" that dominates the newsrooms. (AMARAL, 2002; COOK, 1986; HACKETT, 1993; RODRIGUES, 1993; SOUSA, 2002). That is, researchers point to the prevalence of "official sources", usually connected to the government. It is important to emphasize that the progovernment bias, apart from aiding the journalistic process - for the journalist does not have to seek new sources for each subject covered and also guaranteeing up-to-the-minute information, helps to protect the journalist. If they ever face criticism, the journalists are always allowed to claim that the information was brought to light by an official source, committed to truth and precision as much as the journalists themselves. The source's authority is unlikely to be questioned (TUCHMAN, 1993).

Usage of official sources and focus on official government activities is the first central bias identified by Cook (2005, p. 92) in political coverage. According to the author, topic specialization on the part of the reporters leads them to place political institutions on higher priority levels, emphasizing certain coverage angles that favor certain sources. The ones usually favored are those in a "knowledgeable and powerful position within the official hierarchy, or able to affect the final outcome of processes" (COOK, 2005, p. 93). As was said by Neveu (2006, p. 154), institutional sources are highly important in this process, for they are able to determine the hierarchy and scope of issues and problems.

The authors that analyze the relationship between sources and journalists obviously recognize that sources are not passive, that is, they do not wait for the reporters, but instead act to gain their attention in order to better divulge issues important for them. In this sense, Neveu stresses the procedures leading to professionalization of sources. They develop a strategic ability of anticipating journalistic routines and procedures in order to provide data for information vehicles (NEVEU, 2006, p. 95).

All sources are official ones in an environment such as the Chamber, including those participants in public hearings - members of other government branches, civic society representatives, specialists, etc. Pro-government bias, in that case, lies in the usual choice of leading actors to speak in favor of political positions and committee chairmen to speak for the committees themselves. However, other participants could be used as sources for the arguments taking place in those levels of power.

In the specific case of the Chamber, the choice of institutional sources appears to be a procedure adopted by the professionals in order to dodge political pressures stemming from the deputies themselves. The communication vehicles of the Chamber, either electronic or print, 
are seriously restricted both in the time and space devoted to their activities. Among the various tasks of a competent journalist is to select, from all the facts occurring on a given day, newsworthy facts, since it is impossible to divulge every single event of every nature on a single day. It would not be possible, therefore, to provide coverage for all of the 513 members of the Chamber who are willing to make their statements or present their comments on the nightly TV news or in the newspaper.

Thus, in order not to be accused of political bias, the journalists decided to use institutional importance as a criterion for the choice of sources. Accordingly, party leaders are always preferred for speaking on behalf of a certain political position. If they are not found, vice-leaders are contacted. None of the deputies will be able to accuse the Chamber journalists of either being biased toward a certain position or of being prejudiced against another, since the party leaders are required to speak for their entire political group. The same reasoning works for committee chairmen. It is important to clarify that this hierarchical reinforcement performed by the media does not happen exclusively in Brazil, as Cook (1986, p. 207) points out when mentioning the American Congress.

It is important to observe, however, that the deputies may use legislative processes in order to obtain more media coverage. Disputes for seats in CPIs (Comissões Parlamentares de Inquérito - Congressional Inquiry Committees) occur because these committees' activities are broadly covered by the mainstream media, and this coverage impacts on a deputy's image with the public. There are other less apparent strategies comparable to the latter, such as requiring a public hearing or a topical seminar and applying for participation in the Minor Proceedings Sessions (Pequeno Expediente), that take place before the voting procedures of the day and comprise talks about several topics. In these cases, the deputy is aware that his speech is going to be quoted in the reports on the subject, as he also is aware that Jornal da Câmara will publish the 25 minute speech uttered in the Chamber's main hall at the beginning of voting procedures ${ }^{5}$.

\section{Ethical embarrassments}

In a certain sense, problems revealed by some concerning the lack of proximity to the sources may be credited to a classical concept of journalism, conforming to that of the commercial media. In that traditional concept, the prestigious journalist is exactly the one with exclusive sources and statements. Because of their institutional characteristics, legislative media cannot rely on exclusivity. Their 
main concern is to divulge legislative activity, speaking publicly on behalf of the institution, and not to compete with other media. They also do not publish off the record information, since almost every news report is usually official.

By manifesting journalism's power of choice, the close contact with trustworthy and powerful sources can extend the journalist's participation in the process. That is, on giving up more direct contact with their sources, the Chamber's journalist team may be giving up part of its fact selection powers. As emphasized by Miguel and Biroli (2009, p. 11), "the criteria to define who is to be present in the news arise from journalists" routines and perspectives" and therefore, "choosing the characters that make up the newscast is understood to be a journalist's prerogative, stressed in times of tensions and disputes with other fields (especially the political field) [...]" (MICUEL; BIROLI, 2009, p. 11).

That being the case, it is important to recognize that this distant relationship between journalists and their sources may compromise factchecking on legislative media. In a meeting of the TV Câmara team that took place on May 7, 2010, this subject was brought up. One of the editors affirmed the need to rethink the public hearings coverage and stressed that one of the main issues is the journalist's lack of sources. One of the reporters argued, however, that there is a reason for that: because of the media's official characteristics, the off the record resource cannot be used. "Why would I nurture sources if I cannot use the information provided by them?" she asked.

At this point, two managers mentioned that off the record material is not forbidden and the point is exactly to make more of this unofficial information. But it is one thing if the reporter claims the leader said this or that. A very different situation arises if the report comments on official information and analysis based on information provided by sources that may or may not want to be identified by name. According to some, the reporter will have to take responsibility for an eventual "spoof". The issue is not only the incorrect information but the ones that are published or refuted based solely on political considerations.

One of the main concerns of the professionals concerning editing of informative material is its similarity with mainstream media coverage. Most of them admit that the coverage by legislative media is substantially different from that by the other media, but there is no agreement on whether this difference is acceptable or not. To some journalists, these differences comprise the most censoring situations they are exposed to at the Chamber. As one of them said, "We are scared 
of scoops. If the other vehicles published it before, then I can air it too, but I cannot air it before them. This is a logic which is the opposite of that of mainstream journalism".

Many of the professionals, however, believe there is more journalistic freedom in the Chamber than in other communication vehicles, as shown by the declarations:

I do not believe we are too censored here. A director never reprehends you for doing something or for writing something this or that way. I believe censorship exists much more in a private newsroom, you know what I mean? Of course we have been censored, but we always publish what is truthful (interview given to the researcher).

We end up publishing it one way or the other, but since it is a plural Chamber, there is always going to be complaints. If you publish a report that is not favorable to one of the political forces, there is always going to be a group that will complain, you know? (interview given to the researcher).

Because of the diversity, we have all kinds of groups down here. You have the PSOL (socialist) Party, you have the DEM (conservative) Party, you have Bolsonaro7, you have all kinds of groups, really. You have Clodovil (a fashion stylist who was elected with a large number of votes), you have several sides of an argument (interview given to the researcher).

Journalists of the Chamber signal a crucial difference between legislative media and conventional news vehicles: the pressures suffered by them do not usually stem from advertising clients or the journalistic enterprise, nor do they have an economic aspect. Besides that, these pressures are often not exerted by hierarchical superiors but instead by assistants or the deputies themselves, who act as publishers and utilize their awarded institutional power. This is obviously a stronger privilege of the President of the Chamber and members of the Chamber's governing body $^{8}$. Since these pressures also happen in a naturally conflicting environment, they end up being influenced by the political disputes occurring between the varied groups coexisting in the Chamber. In a certain way, these cross pressures stemming from several actors and parties cancel each other, as the interviewees stress.

There is pressure, it is inevitable. In a political venue, there is no running away from that. I have worked for a long time in mainstream media and I do not know if we have to endure more pressure here than outside. Sometimes I believe the opposite is true. Several journalists believe they will have total freedom when working in mainstream media, and that is not true. Assignments are biased, reports are prohibited when they are about to be written and sometimes they are ready and are not published. There are reports the professionals work on, sometimes even unknowingly, that were previously commissioned to be written. The company has its own political and economic interests. There 
are 513 deputies, I believe there being so many of them helps us, because it weakens the pressures on us. The deputies who obviously pressure more are the ones in the Chamber governing body, the ones in leadership roles. Yet I believe we are in a great situation (interview given to the researcher).

Since we are influenced by all 513 deputies, we naturally, I mean, so-to-speak naturally, believe the reports and their results will be unbiased. I trust very much the information we divulge here (interview given to the researcher).

We are free to work within the Chamber, though many people do not believe this to be true, it is. We have much more freedom than, I would dare say, any other legislative vehicle in the country. There are 513 deputies, if you consider this power is scattered among 513 people, 513 different opinions, several parties; the fact that the power is scattered gives us greater freedom to act (interview given to the researcher).

When commenting on journalistic autonomy as compared to the remainder of social spheres, Neveu affirms that the logic of incessantly seeking profit can diminish the distance between the writing staff and their sources, which would allow more "exchanges between the writing staff and the official speeches" (NEVEU, 2006, p. 73). That happens when, according to the author, there is little investment in team size and quality and in resources necessary for research and investigative journalism. Perhaps that is the point of the Chamber's journalists: because they are not commercially oriented, legislative vehicles do not possess the same resources as conventional media. At the same time, political pressures occur fiercely within a political institution and end up being neutralized by the diversity of political groups acting within a legislative body the size of this Chamber. In this way, the journalists feel freer to act, when comparing their situation with that of journalists working for other vehicles, either official or commercial.

\section{Conclusion}

An issue that appeared in many of the statements by the professionals is their concern with source, opinion and political diversity in their media. For many of them, this diversity would serve as an alternative to the procedures of conventional media and to the prioritizing only of official sources. To some of them, this occurs currently during the coverage, because of the public diversity within the Chamber itself.

Since we do have a huge plurality among the deputies, we end up with the same plurality of opinions, and this is beneficial for us (interview given to the researcher).

And I believe we voice a lot of minority issues. People working here value that aspect, so we end up divulging many causes, we 
fight for the little man... (laughs), minority causes, women, AfricanBrazilian individuals, gay people, transsexuals, HIV positive people, rural workers. I believe all these minorities have a lot of space on our TV (interview given to the researcher).

To some other journalists, this diversity is an ideal yet to be conquered and has to do with practical issues on their activities. They still urge for more freedom and autonomy from sources and hierarchical superiors. This is more difficult to acquire within the Chamber, because of its undeniable official facet.

\begin{abstract}
They want the managing of the vehicles to be less centralized, to be managed differently, allowing them to have different scope. This is abundance of information, a plurality of scopes in our coverage grounds (interview given to the researcher).

It would be ideal to open the Chamber to every civic entity to put forth its opinion on each of projects discussed in here, or at least, the ones with direct interests being discussed. That is impossible, though. We are limited by the vehicle's framework. And it is also difficult to contact all these entities, all the ones familiar with the subject and that wish to voice their opinions on the matter (interview given to the researcher).
\end{abstract}

We have already stressed that diversity of sources, opinions and scopes is one of the prerequisites for media vehicles to accomplish their role as facilitators of the public debate. The media should serve as spokesmen for social demands. They should represent the population groups that are not well represented in formal governmental institutions. One proposal in order to attain more media diversity is the concept of "regulated pluralism", coined by John Thompson (1998). Its goal is to avoid the concentration of ownership in the news making market and regulate media and media proceedings. For instance, by emphasizing the public service side of the media, guiding companies so that information and entertainment are not treated as products (MICUEL, 2004, p. 139).

From the perspective of serious public communication, it is fair to stress that legislative vehicles need to represent several different social spheres in the society, a subject already approached by other authors with respect to the general media (ALDÉ, 2004; KEANE, 1996; LATMANNWELTMAN, 1996; MAIA, 2006; MIGUEL, 2003). It should be done in a way that also stresses the principle of "information as a social right", not only a political need of the government to publish its actions (MACHADO; MOREIRA, 2005).

Among the journalists interviewed for this research, many believe that greater autonomy of the teams and increased separation between journalism and institutional communication might improve the quality of information in the Chamber. That improvement would benefit 
information as well as improve contact with the different audiences targeted by the institution. Some others argue that the Chamber's communication branch should take advantage of its political place and work more on institutional and electoral aspects of news making.

Despite disagreements within the team itself, it seems indispensable to stress a point of the discussion that has appeared in the interviews: diversity, both source and subject diversity and points of view or scopes regarding the debated issues; diversity of voices and of versions of the political facts; diversity of representations and of opinions, so that social demands may become visible and all portions of society may in fact participate in a democratic public debate, as urged by Nancy Fraser.

\section{| NOTES}

1 The method of participant-observation of news making routines in the four legislative media was performed by the author between the years of 2007 and 2009 in order to obtain a Ph. D. in Political Sciences in 2010. Several in-depth interviews with 43 professionals of Secom (Communication Secretariat) were another technique used to complete the project.

2 Acronym of Secretaria de Comunicação (Communication Secretariat) in Portuguese.

3 Chamber of Deputies Act \# 96, dated 6/19/1998. TV Câmara and Rádio Câmara were created in October 1997, but only went on the air in 1998 and 1999, respectively.

4 It is important to note that the deputies maintain their own communication structures, organized by their office employees. These employees are not, in most cases, Government employees, but rather professionals hired directly by the deputies.

5 The deputies' order of speaking during the Grande Expediente (Main Proceedings Session) is determined by lot.

6 "Spoof" is the term used in the Brazilian journalistic lingo to characterize misinformation published by an information vehicle.

7 Jair Bolsonaro is a federal deputy from Rio de Janeiro who is known for his polemic declarations. 
8 It is common, in all of the Chamber's vehicles, for the editors or directors to apologize to reporters or editors ordered to do institutional reports with which they do not agree themselves, but which have to be reported nonetheless. In these situations, it is standard to hear that: "I also find it absurd, but the deputy required it...". More so than in mainstream newsrooms, there seems to be some "solidarity" between superiors and subjects within the legislative newsroom. They have to unite against the "external forces" pressuring their news making routines: the deputies' political power.

\section{BIBLIOGRAPHY}

ALDÉ, Alessandra. A construção da política: democracia, cidadania e meios de comunicação de massa. Rio de Janeiro: Editora FGV, 2004.

ALSINA, Miquel Rodrigo. La construcción de la noticia. Barcelona: Paidós, 1989.

AMARAL, Márcia Franz. Fontes jornalísticas: o Lugar de Fala do cidadão. Trabalho apresentado no Núcleo de Pesquisa em Jornalismo, XXV Congresso Anual em Ciência da Comunicação, Salvador/ BA, Sept. 4 and 5, 2002.

BLUMLER, Jay G.; GUREVITCH, Michael. Journalists' orientations to political institutions: the case of parliamentary broadcasting. In: GOLDING, Peter; MURDOCK, Graham; SCHLESINGER, Philip. Communicating Politics. New York: Holmes \& Meier: Leicester University Press, 1986. p. 67-92.

CANTANHÊDE, Eliane. O jornalismo e a "fonte" - Muito trabalho, bastante credibilidade e uma pitada de bom senso. In: SEABRA, Roberto; SOUSA, Vivaldo de. Jornalismo Político. Teoria, História e Técnicas. Rio de Janeiro: Record, 2006. p. 181-192.

CHARAUDEAU, Patrick. O discurso das mídias. São Paulo: Contexto, 2007.

COOK, Timothy. House members as newsmakers: the effects of televising Congress. Legislative Studies Quarterly, v.11, n.2, p. 203-226, May 1986.

Governing with the news. The news media as a political institution. 2 ed.. Chicago: The University of Chicago Press, 2005.

FONTCUBERTA, Mar de. La noticia. Pistas para percibir el mundo. Barcelona: Paidós, 1993.

FRASER, Nancy. Rethinking the Public Sphere: a Contribution to the Critique of Actually Existing Democracy. In: CALHOUN, Craig (ed.). Habermas and the Public Sphere. Cambridge/MA, London: The MIT Press, 1992.

HONNETH, Axel. Redistribution or recognition? A Political-

Philosofical Exchange. London: Verso, 2003. 
GANS, Herbert J. Deciding what's news. A study of CBS Evening News, NBC Nightly News, Newsweek and Time. $25^{\text {th }}$ anniversary ed.Evanston/ Illinois: Northwestern University Press, 2004.

GONÇALVES, Rogério Mozart Dy Lá Fuente. O super-homem pendura o paletó na repartição: a gênese do jornalista legislativo. 2010. Dissertação. (Mestrado em Comunicação Social). Programa de PósGraduação da Faculdade de Comunicação Social, Universidade de Brasília (UnB), Brasília.

HACKETT, Robert A. Declínio de um paradigma? A parcialidade e a objectividade nos estudos dos media noticiosos. In: TRAQUINA, Nelson. (org.). Jornalismo: questões, teorias e "estórias". Lisbon: Vega Ltda., 1993. p. 101-130.

KEANE, John. Transformações estruturais da esfera pública. Comunicação \& Política. Rio de Janeiro: Centro Brasileiro de Estudos Latino-americanos, vol. 3, número 1, p. 6-28, Jan.-April 1996.

LATTMAN-WELTMAN, Fernando. A "esfera pública": do conceito à palavrade-ordem. Comunicação \& Política. Rio de Janeiro: Centro Brasileiro de Estudos Latino-americanos, vol. 3, número 1, p. 160-175, Jan.-April 1996.

MACHADO, Márcia Benetti; MOREIRA, Fabiane. Jornalismo e informação de interesse público. In: Revista Famecos. Porto Alegre: PUC/RS, número 27, p. 117-124, Aug. 2005.

MAIA, Rousiley. Política deliberativa e tipologia da esfera pública. Bauru, XV Compós, 2006. Trabalho apresentado ao GT Comunicação e Política.

MIGUEL, Luis Felipe. Representação política em 3-D. Elementos para uma teoria ampliada da representação política. Revista Brasileira de Ciências Sociais, vol.18, número 51, p. 123-140, Feb. 2003.

Modelos utópicos de comunicação de massa para a democracia. Comunicação \& Política, vol. 22, número 3, p. 129-147, Sept.-Dec.. 2004.

BIROLI, Flávia. A produção da imparcialidade: a construção do discurso universal a partir da perspectiva jornalística. Belo Horizonte/ MG, XVIII Encontro da Compós, June 2009. Trabalho apresentado ao GT Comunicação e Política.

NEVEU, Érik. Sociologia do jornalismo. São Paulo: Edições Loyola, 2006.

QUEIROZ, Dulce. Jornalismo institucional nas TVs legislativas. Os casos do Brasil e do México. 2007. Dissertação. (Mestrado em Comunicação Social). Programa de Pós-Graduação da Faculdade de Comunicação Social, Universidade de Brasília (UnB), Brasília.

RODRIGUES, Adriano Duarte. O acontecimento. In: TRAQUINA, Nelson (org.) Jornalismo: questões, teorias e "estórias". Lisbon: Vega Ltda., 1993. p. 27-33.

SANT'ANNA, Francisco. Mídia das fontes. O difusor do jornalismo corporativo. Brasília: Casa das Musas, 2008.

SOUSA, Jorge Pedro. A objectividade: da filosofia ao jornalismo, 
passando pelas ciências. Porto: Universidade Fernando Pessoa, 2000. Lecture.

Teorias da Notícia e do Jornalismo. Florianópolis: Argos, 2002.

THOMPSON, John B. A mídia e a modernidade. Petrópolis: Vozes, 1998.

TRESCH, Anke. Politicians in the Media: Determinants of Legislators' Presence and Prominence in Swiss Newspapers. The international Journal of Press/Politics. London: Sage, volume 14, p. 67-90, Jan. 2009.

TUCHMAN, Gaye. A objectividade como ritual estratégico: uma análise das noções de objectividade dos jornalistas. In: TRAQUINA, Nelson. (org.). Jornalismo: questões, teorias e "estórias". Lisbon: Vega Ltda., 1993. p. 74-90.

Cristiane Brum Bernardes is $\mathrm{PhD}$ in Political Science from Institute of Social and Political Studies, Rio de Janeiro State University (IESP/ UERJ) (2010). Master in Communication and Information from Federal University of Rio Grande do Sul (UFRGS) (2004). Professional journalist, legislative analyst of the Chamber of Deputies, acting on TV Câmara. Lecturer and researcher in Postgraduate Program of Center for Training and Improvement (CEFOR) of the Brazilian Chamber of Deputies.

E-mail: ccris.brum@gmail.com or cristiane.bernardes@camara.gov.br 